\title{
Teacherly aesthetics: Literature and literacy in Binyavanga Wainaina's works
}

\section{Ruth S. Wenske}

\section{Teacherly aesthetics: Literature and literacy in Binyavanga Wainaina's works}

In this paper I use the concept of teacherliness to explore the connections between literature and education in Binyavanga Wainainas memoir One Day I Will Write About This Place and his opinion pieces on education. I read Wainaina's texts against the way the literature/literacy duality has been envisioned in historical discourses, arguing that deeper pedagogical questions were largely overlooked in the intersections between the two theoretical fields. To address this lacuna, I use Paulo Freire's theory of Critical Pedagogy to analyze historical debates of curriculum and canonization, as well as Wainaina's more recent engagement with the Kenyan educational system, in which questions on how to write are intertwined with thoughts on how to teach. After detailing this history of literature and literacy in East Africa, I explore the themes and aesthetic devices that Wainaina develops in One Day to reflect on his own role as an educator in the context of his troubled relationship with his own schooling. By focusing on the theme of failure and Wainaina's embedding of oral structures into his text, I suggest Wainaina's work offers insights and concrete narrative patterns that might become fruitful tools through which educational theory and literary analysis might illuminate each other's blind spots, specifically in regard to oral skills in education. Keywords: African literature, autobiography, critical pedagogy, self-writing, orality, teacherliness, Binyavanga Wainaina.

\section{Introduction}

When selected as one of Time magazine's "100 most influential people of 2014", Chimamanda Adichie described Binyavanga Wainaina as "[t] he best-known Kenyan writer of his generation". Though he only published one book, his acclaimed memoir One Day I Will Write About This Place, before his untimely passing in 2019, Wainaina left behind a large collection of short stories, essays, video speeches, and interviews. This includes the sardonic short essay "How to Write About Africa", the most forwarded article in Granta's history, and "Discovering Home", which won the 2002 Caine Prize. Yet his success, rivaled by few contemporary authors, is also largely due to his activism and public persona. Among Wainaina's most influential acts was his public coming out in the essay "I Am a Homosexual, Mum" in January 2014, published on three websites simultaneously as a lost chapter from One Day. As Neville Hoad writes, Wainaina's advocacy for gay rights in Kenya made him into "an emblematic African homosexual" (188). Equally important was Wainaina's establishment of Kwani?-a literary magazine aimed at publishing work by new Kenyan writers (Hoad 186). Against criticism of Kwani?'s reliance on donors, Jeanne Marie Jackson describes its success in becoming "a nursery for a good many other home-grown talents and texts" (261). Thus, though Wainaina's acclaim reverberated throughout Africa and beyond it, his literary and political activism was most immediately targeted at, and felt in, East Africa.

My point of departure in reading Wainaina is that he was operating within, and against, a specific East African tradition that has its roots in the 1960s, in which literature and education are read side-by-side. This tradition has since followed a dual literature/literacy trajectory, where ongoing discussions on the links between literature and education range from disputes around the set books in secondary schools' curricula to the wellknown language debate that links the language of literary production to Literature-in-Education (LIE) policy. Kwame Anthony Appiah states the importance of recognizing this connection in the study of African literature, emphasizing its pedagogical aspects:

The role of the colonial—and, alas, the post-colonial—school in the reproduction of Western cultural hegemony is cru-

cial to African criticism because of the intimate connection between the idea of criticism and the growth of literary

Ruth S. Wenske is a postdoctoral researcher at the Martin Buber Society of Fellows at the Hebrew University in Jerusalem, Israel, and the head of the Africa Unit at the Harry S. Truman Research Institute.

Email: noruthie@gmail.com

(D) https://orcid.org/0000-0003-2246-6867

DOl. https://doi.org/10.17159/tl.158i1.8353

DATES:

Submitted: 17 May 2020; Accepted: 29 November 2020; Published: 5 May 2021 
pedagogy: for the role of literature, indeed, the formation of the concept, the institution of "literature," is indissoluble from pedagogy. (61)

As one aspect of this literature/literacy tradition, I suggest that Wainaina's use of aesthetic patterns, defamiliarizing metaphors, and anthropomorphism foreground a kind of pedagogy, where how to write raises questions regarding how to teach, combining teacherly literary aesthetics and teacherliness as pedagogy. These readings seek to move beyond existing debates on the literature/literacy connection, which have become entrenched in questions of what to write (and read) and what to teach — questions of syllabi, curricula, set books, and canonization. To this end, I reflect on the text's pedagogical registers, which link literature and literacy in new ways.

Here I adopt Harry Garuba's framework of the "teacherly text" to explore how teacherliness has changed over the last sixty years, marking a transition from top-down didacticism to processes "through which a new unlearning and learning may begin" (29). The new teacherly model that Garuba develops replaces the understanding of teacherliness as top-down authoritative learning with pedagogy that is dialogical and open-ended:

The teacherly task conceived as a hierarchical passing down of knowledge between teacher/leader and pupil/people has given way to a more 'democratic' model, in which thematizing the issues in ways that provoke discursive engagement now appears to be more prevalent. This is understandable because $[. .$.$] the issues that agitate the contemporary crop of$ writers are not as amenable to neat resolutions and discursive closure. (Garuba 17)

My main argument is that Wainaina's writing, much like his efforts to publish a new generation of Kenyan authors, attempts to revolutionize East African literature by introducing this kind of teacherliness as an aesthetic and pedagogical foundation of creative writing. In order to better grasp this use of teacherliness in One Day, I begin with a brief contextualization of this model within educational thought, since Garuba's framework runs parallel to debates that are taking place in educational criticism, specifically in East Africa. Furthermore, Wainaina himself has authored critiques of the Kenyan educational system which echo these educational paradigms, giving further grounding to such readings in the East African context. I will then use the insights from educational theory to reflect on the historical discussions around literature and literacy, and consequently, to read One Day as a teacherly text in which failure and success are central motifs towards challenging old conceptions of teacherliness.

\section{Educational theory and literary teacherliness}

Garuba's teacherly model cited above is based on a type of pedagogy that has become increasingly popular over the past decades: learner-centred education (also called child-centred pedagogy, or CCP). Martial Dembélé and Pulane Lefoka describe CCP as participatory and interactive learning that is grounded in the learner's immediate environment, "with a view to fostering conceptual understanding, critical thinking, and problem-solving skills" (536). Like the new teacherly text, CCP is based on dialogical learning, where "open-endedness is deliberately offered as an invitation to discussion and debate" (Garuba 19). Learner-centred education is becoming increasingly popular also in East Africa, where traditional teaching practices are considered "as teacher-centred, lecture-driven, rigid and authoritarian" (Altinyelken 152). In Kenya, the Competency-Based Curriculum (CBC) introduced in 2017 marks such a large-scale reform, which aims to shift top-down exam-oriented learning to a focus on the skills that young people need in the work market and as citizens.

According to the website of the Kenya Institute of Curriculum Development, the CBC is meant to instill

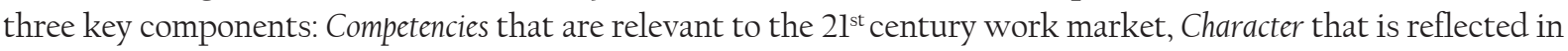
personal values and parental involvement in education, and Creativity aimed at problem solving and innovation. These are precisely the competencies that Wainaina described as missing from Kenyan schools, both in his memoir and in his more direct engagements with education. Wainaina's short essay "Schooling for Small Minds", published three years before One Day, critiques schools in Kenya for being places where "[i]deas have no value", where "[e]very bit of creative thinking, of bold idea-ing, of do-it-yourselfing is removed", and where the end result is "brain-dead robots". Indeed, he points to the many absurdities that people accept due to this lack of independent thinking, for instance the pressure to go to university when there are no jobs for graduates. His message- that learning should be more creative and geared towards critical thinking-is precisely that of the new Competency-Based Curriculum.

Moreover, Wainaina holds the government responsible for education being elitist and corrupt, which are the same problems that Maurice N. Amutabi cites as the reasons that the CBC reform was introduced. (Amutabi 
describes how parents would bribe head teachers, enroll their children in several schools, and encourage cheating. The 8-4-4 curriculum - the pre- $\mathrm{CBC}$ curriculum - thus served the elite and fostered cut-throat competition, while overlooking the skills and knowledge young people need in $21^{\text {st }}$ century Kenya.) Wainaina traces this to the colonial history of education, which undermined critical thought as part of its design to foster a class of civil servants: "We took the colonial system, which was designed to produce dutiful people who don't ask questions, and perfected it" ("Schooling for Small Minds"). This criticism resonates with Paulo Freire's influential approach of Critical Pedagogy, proposed in his 1970 book Pedagogy of the Oppressed. Freire argued that formal education exacerbated inequality in postcolonial settings where elites were already in place and literacy levels were low. He claimed that schools became another structure of domination that effectively preserved colonial hierarchies because the elites sought to maintain the status quo (94), using passive "banking education" to keep the masses from developing independent thinking or questioning authority (72-3).

Wainaina develops these ideas in a series of video essays titled "We Must Free our Imaginations". Published just three days after his widely publicized coming out in January 2014, the video essays focus on the links between schools, creativity, and writing, advocating for an educational system that "makes us think and innovate" ("We Must Free our Imaginations (1/6)", 2:54). Lamenting the lack of critical thinking and Kenyan society's over-emphasis on certificates, science, IT, and religious dogma, Wainaina prescribes creativity as the remedy for society's many ills: "To make new things we have to imagine, it's just simple. So, when you say you remove art from school so people can become scientists—now with what imagination?" "We Must Free our Imaginations (6/6)", 1:35)

Furthermore, Wainaina emphasizes this creativity as a political act, much like Freire's idea of 'conscientization', conscientização in the original, connoting dialogical or 'problem-posing' learning that foregrounds learners' agency and knowledge (104-9) and raises learners' political awareness (147). Wainaina sees this as the basic connection between literature and teacherliness: "I want this generation of young parents to have their kids see Africans writing their own stories, printed their own stories, that simple act, I think that's the most political act that one can have" ("Imaginations (1/6)", 0:27). Whether or not Wainaina's activism influenced CBC's introduction in Kenya is speculative and beyond the scope of this paper. But though the implementation of $\mathrm{CBC}$ faces severe challenges, much like similar reforms in East Africa, it marks an important development that again shows how educational and literary discourses follow similar and interconnected trajectories.

There is of course a difference between educational practice/theory and literary scholarship. The connection between old-school, top-down didacticism and the colonial system has certainly been challenged in the literary context, where the first generation of African writers was already invested in dismantling colonial legacies. For instance, the university memorandum "On the Abolition of the English Department", written by Ngũgĩ Wa Thiong'o (then James Ngugi), Taban lo Liyong, and Henry Owuor-Anyumba, sought to "reject the primacy of English literature and cultures" (94), as Ngũgĩ writes in Decolonising the Mind. The three lecturers from the University of Nairobi argued for "placing oral-literature (orature)", as well as "Kenya, East Africa, and then Africa" (qtd in Ngũgĩ wa Thiong'o 94) at the centre of the syllabus, suggesting that "the English Department be abolished [and] that the Department of African Literature and Languages be set up in its place" (Ngũgĩ wa Thiong'o, Lo Liyong, and Owuor-Anyumba 439). Yet it never occurs to the three authors to question the very structure through which they make these claims: the university itself, and its teacher-centred structures that saw the European-educated professors as the ultimate teachers of modern Kenya.

Though "Abolition" certainly adopts certain tenets of Critical Pedagogy in challenging the Eurocentric curriculum, the $\mathrm{CBC}$ proposes an important addition in challenging the exam-oriented and unequal structures of formal education more broadly. This is the reason I maintain that it makes sense to read literature-and in this case literary teacherliness-alongside educational theory. In the last part of this article, I return to this premise, and look more closely at how Wainaina's negotiation of teacherliness also critiques certain aspects of learner-centred education. But I start with a brief historical overview in order to understand how intrinsically the idea of teacherliness it is tied to the East African literary scene, suggesting that it is no coincidence that a Kenyan author is the one to challenge these literature/literacy conceptions.

\section{Historical background}

The Conference of "African Writers of English Expression", which was held at Makerere College a few months before Uganda gained its independence in 1962, needs little introduction. As Peter Kalliney puts it, the conference "announced the birth of postcolonial African literature in English [and] started the debate about the appropri- 
ateness of using imperial languages in literary production" (349). Furthermore, Mũkoma wa Ngũgĩs recently published book The Rise of the African Novel: Politics of Language, Identity, and Ownership sees the conference as a watershed moment in the canonization of African literature, as it "derailed the African literary tradition from one of writing in African languages and subsequently getting translated into other languages, and started us on the path of the realist African novel in English" (17). Kalliney also notes that the focus on the polemical language question has been so pronounced that it has obscured other aspects of the conference-for instance the participants' overwhelming focus on literary technique (342) and modernist aesthetics (350). It is this sort of aesthetic focus that I wish to regain by tracing how pedagogy has been overlooked as a legacy of the Makerere conference.

An episode that encapsulates this oversight is the debate following Obi (Obiajunwa) Wali's 1963 article "The Dead End of African Literature" in Transition. Wali writes that "the secondary place which African languages now occupy in our educational system would be reversed if our writers would devote their tremendous gifts and ability to their own languages" (14-5). To this, Es'kia (then Ezekiel) Mphahlele replied in the next issue of Transition that Language-in-Education policies were largely decided by colonial administrations and cannot be the responsibility of writers. Mphahlele uses the notorious example of Bantu education in South Africa to further argue that the aim of using African languages in schools is "obviously to arrest the black man's education" (8). Wali and Mphahlele differ on their view of curriculum: while Wali claims that writers should supply materials for teaching African literature up to university level (15), Mphahlele disagreed, arguing that "literature can be kept on an infantile level is by promoting a school literature in such a way that the man who wants to write for an adult audience does not stand a chance of being published" (9).Yet, while they quarrel about the role of literature vis-à-vis language and curriculum, Mphahlele and Wali do agree on these as crucial links between literature and education. Therefore it never occurs to them to question the pedagogical structures of schools or universities, which were also European imports and were pivotal to the questions they debate-much like the authors of "Abolition" after them.

The legacy of this debate endures, as is evident in the way it shapes Wa Ngũgîs recent intervention regarding East African education in his book. Like Wali and Mphahlele, Wa Ngũgĩ envisions education and the literary scene as closely intertwined: he speaks of how language policy in school affects authorship in Kenya (chapter one), he goes into detail regarding the rationale of educational publishing of both textbooks and fiction (chapter four), and finally, he discusses the impact of these on the canon of African literature and the privileging of the realist novel over popular genres. While Wa Ngũgĩ seeks to challenge this aspect of what he calls the Makerere legacy, he considers the literature-literacy connections in three emblematic ways that all have their roots in the 1960s Makerere milieu: questions of language (Europhone vs. African languages), questions of syllabi and curriculum, and questions of publication (textbooks and set books) and canonization. ${ }^{1}$ Wa Ngũgĩ like Wali and Mphahlele, also never questions the pedagogical methods or structures of schools, nor the effect this has on economic and social capital, as well as creativity and imagination. Yet educational thought, and specifically tenets of Critical Pedagogy and how these are implemented in the $\mathrm{CBC}$, might be useful for thinking in new ways about the impact of formal structures of schooling on the East African literary scene.

The tendency to reduce links between education and literature to several technical aspects is evident in an episode that is largely forgotten in literary history. For in the first two weeks of January 1961, another large-scale international conference, with over 60 representatives from 23 Commonwealth countries, took place at Makerere: "The Commonwealth Conference on the Teaching of English as a Second Language". As Robert Phillipson writes in Linguistic Imperialism, the conference was a seminal event in the field of English Language Teaching in Third World countries, known for perpetuating the fallacy that native speakers are the ideal language teachers (194). The conference is well-known in educational circles but is never mentioned in a literary context. This in spite of its focus on how "language and literature should be brought together, and examined together" (18), as the conference report states.

While the two conferences were from different disciplines and catered to divergent audiences, both centred on the use of English as a second/foreign language in multilingual and soon-to-be postcolonial societies. Indeed, the 1961 conference report shows how central the question of literature was in the teaching of English. ${ }^{2}$ What is more, the two conferences - together - set the stage for the links that would come to dominate how African educators and intellectuals would come to think of the literature-literacy connection. Two attendees of the 1961 conference in particular brought these ideas into wider circulation. One was Norman MacKenzie, an English professor from the University of Rhodesia and Nyasaland, who had in 1959 published the essay "The Place of English 
in African Education". MacKenzie's writing brought together Language-in-Education policy with readings of Achebe and Tutuola and had direct influence on the overwhelming use of English in schools in ex-British colonies, as well as the canonization of Achebe and his conception and use of English in African literature. Recently, Wa Ngũgĩ revisited MacKenzie's role in perpetuating Eurocentric views of African languages, cultures, and fictional writing (Rise 19; 36-7). Additionally, Norman (Derry) Jeffares was arguably the attendee of the 1961 conference who had the greatest impact on African literature in years to come. As Chair of English Literature at the University of Leeds, Jeffares hosted the first Conference of Commonwealth Literature in Leeds in 1964, which Alastair Niven calls "one of the most influential conferences in the field of English studies in Britain in the twentieth century" (143). ${ }^{3}$ The keynote speaker at the 1964 conference was Chinua Achebe with his well-known essay "The Novelist as Teacher" (later published in Commonwealth Literature, the conference proceedings edited by John Press). Garuba, as others before him, identifies Achebe's essay as instrumental in making didactic 'teacherly texts' the modus operandi for the first generation of African writers, as "this 'teacherly' task [was] part of the responsibility of the entire class of decolonizing nationalist intellectuals" (15).

Like Garuba, Ainehi Edoro singles out Achebe's essay as the moment that established "the traditional notion of the African writer as a social figure and the notion that writing is a powerful tool for collective action against social power" (30-1), even as she traces how this notion is moving away from Achebe's original top-down didactic model. Though Edoro does not directly speak of open-ended teacherliness, she also critiques the idea that the author, as Achebe's novelist-teacher or Wole Soyinka's "social visionary", imparts knowledge as an expert set apart from society. Instead, Edoro highlights how the author is embedded in society: "how ideological constraints and material conditions construct the creative mind and define the nature of its creative functions and relationship to the collective" (30).

It might be a coincidence that Jeffares - after attending the 1961 conference that stressed the importance of literature in the teaching of English - became a close associate of Achebe, and that their acquaintance was instrumental to the publication of Achebe's landmark essay. Yet my point is that ideas from the different gatherings were being shared and disseminated, thus no doubt influencing what was slowly coalescing into the mainstream, or the canon, of modern African literature.

Reports from subsequent conferences of the Association for Commonwealth Literature and Language Studies (ACLALS), including another one at Makerere in 1974, all demonstrate a preoccupation with these three specific links between literature and education: the language of writing vs. Language-in-Education in schools, curricula/ textbooks vs. publishing/canonization, and the idea of the novelist's social responsibility as teacher. For instance, C. D. Narasimhaiah reports that in the ACLALS 1971 Jamaica conference, Kamau (then Edward) Brathwaite, V. S. Naipaul, and Raja Rao held a panel on "the Writer's Function in Society" (121), while John Spencer went into dilemmas of bilingualism and the importance of "societies learning their own languages before they learnt English" (125). Anniah Gowda, reporting from the 1974 ACLALS conference at Makerere, mentions four writers who raise a related question: Trinidadian Arthur Drayton, who had also attended the 1962 Makerere conference, presented a paper "which argued that the writer should involve the masses in his medium" (220); Somali Nuruddin Farah, whom Garuba uses as his example of the new generation of 'teacherly' writers, talked about Somalia's efforts to develop a literature of its own (221); and Peter Nazareth's essay "The Social Responsibility of the Third World Writer: An African Dialogue" criticized authors who wrote for the colonial masters and elite rather than the people, to which Achebe added a paper entitled "Colonialist Criticism", which asked African critics "to take control of our literary criticism" (qtd in Gowda 222). Both conference reports mention Norman Jeffares as instrumental in organizing the conferences through his work with ACLALS.

These are the links that Wainaina's writings challenge. For as Garuba's argues, "the 'teacherly' pillar of postcolonial aesthetics and literary culture has not been taken as seriously as it should, as it is often confused with a didacticism seen as going against the grain of contemporary conceptions of literature" (18), thereby obliterating new evolving conceptions of the literature and education link. Here Wainaina's teacherly ethos, which draws on tenets of Critical Pedagogy and combines it with an aesthetic focus, brings together what he writes about and how he writes it. Also, his activism, which builds on his critiques of schooling in Kenya, constitutes an element of this new form of learner-centred teacherliness, albeit one in which textual and referential factors require some untangling. 


\section{Literature and literacy in the works of Binyavanga Wainaina}

When Wainaina passed away in May 2019, the web was flooded with dozens of tribute essays that portrayed Wainaina not only as an exceptional author, but also as a mentor. ${ }^{4}$ For instance, Wainaina's friend and colleague at Kwani? Parselelo Kantai writes: "It is almost unbelievable how many people Binyavanga touched, how many lives he quite literally transformed in the decade and a half that he worked as a writer and activist. [...] He freed a generation to begin imagining itself into being". Christine Mungai, who did not know Wainaina personally but rather got to know him by reading Kwani?, likewise asserts: "Binyavanga Wainaina inspired me and a whole generation of Kenyans to put pen to paper. I would not be a writer today if it wasn't for Binyavanga Wainaina". Indeed, according to Wa Ngũgĩ 's article "Our Man of the People", "Binyavanga was my generation's conscience, our James Baldwin and Achebe rolled up in one".

Without going into Wainaina's personal life, I mention these testimonies as they outline a fundamental aspect of the teacherliness that he negotiates in One Day: his combined focus on the what and how of writing and teaching. Yet precisely because Wainaina's educational zeal is so easily grounded in popular discourse, my close readings aim to zoom in on how teacherliness is constructed as an aesthetic and poetic layer of the text. Here I follow Elleke Boehmer's suggestion to move beyond the reductive view of 'postcolonial aesthetics' as an oxymoron, which has "led critics to overlook or side-step questions of poetics as the 'real world' issues it has sought to confront have appeared by contrast so urgent" (1). As a challenge, Boehmer asks, "How could postcolonial writing be both political and concerned with formal and even aesthetic principles?" (19, emphasis in original)

Teacherliness becomes an answer to this question. Much like Garuba's argument regarding novels that do not "offer the kind of closure or neat resolution that the ideologically driven programmatic text requires" (19), I consider Wainaina's works for their self-reflexive engagement with literature and literacy, so "that their open-endedness is deliberately offered as an invitation to discussion and debate" (Garuba 19). This open-endedness is often a matter of the text's form and narrative techniques rather than its content. After all, One Day is not a thriller: we know the story ends with Wainaina becoming a successful writer. What remains uncertain, as if left to be endlessly re-constructed, is the very process of narrativization that makes the past present and gives it meaning; for turning memory into narrative changes the past, so to speak. Wainaina's coming out through a "lost chapter" from One Day highlights this unfinishedness quite clearly, as "I am a Homosexual, Mum" draws attention to the almost-complete absence of romantic and sexual layers in Wainaina's memoir, thereby changing how certain episodes are now read.

\section{Autobiographical self-reflexivity as teacherliness}

One Day details Wainaina's coming-of-age in Kenya in the 1980s and 90s, starting from early childhood and following him until he becomes a successful writer. Throughout the narrative, Wainaina often uses a stream-of-consciousness-like narrative voice that mimics a child's (later youth's) point of view, which highlights the specific stakes of representation within the genre of the autobiography. As Roger Berger writes, African biographies in particular carry a burden of referentiality as they "must account both for the synchronic realities that emerge from the localized experience of specific writers and for the diachronic, historical developments that presented different imperatives for different historically situated writers" (47). In line with this referential impetus that sees autobiography as representative of collective processes, critical readings on One Day have so far focused on its negotiation of the nation/nationality (Krishnan) and political representation (Knighton).

At the same time, as an act of-self representation, the autobiography is always haunted by the subjectivity and narrativization of seeing oneself. Daphna Erdinast-Vulcan notes that "the problem with self-writing is that it is precisely the doubleness of the first person perspective which makes it impossible for the self to 'tell itself"' (5). Consequently, according to Philippe Lejeune, "the paradox of the literary autobiography, its essential double game, is to pretend to be at the same time a truthful discourse and a work of art" (124). In other words, mimetic referentiality is not the only-sometimes not even the primary-yardstick of the autobiography. Equally important is the author's process of self-representation, as it is the site that brings together the narrated and the experienced; indeed, where questions regarding the boundaries between narrative construction and its real-world referent-between text and context — can be brought up. To separate the two, I use the name Binyavanga to refer to the speaker in One Day, in order to distinguish him from Wainaina the author.

In One Day, Binyavanga's Bildung as a writer is what brings text and context together. Wainaina foreshadows his process of becoming a writer by describing his obsession, from early childhood, with the way language 
conveys meaning. This, in my reading, becomes a kind of teacherly aesthetic, where self-reflexive engagement with literacy - in the sense of lexicon, grammar, and style - become the foundation for Binyavanga's literary aspirations. An early technique for establishing this self-reflexive emphasis is Wainaina's use of anthropomorphic metaphors, which play on uncertainty and open-endedness rather than pinning down meaning: "My new word bureaucrat is running around my mind in a panic, stamping and coding and reminding me to never forget that one day, one day I will arrange the words right for this strange night" (52, emphasis in original); "I do not have enough words for all this. [...] Words must surround experience, like Mum's new vacuum cleaner, sucking all this up and making it real. Whoosh" (53, emphasis added).

Through the use of anthropomorphism, the narrative voice seems to try to capture the impossibility of representation. In the words of George Levine: "Language, finally, can 'represent' only other language" (8), so that "language, in representing reality, most forcefully demonstrates reality's absence" (7). Yet Binyavanga contradicts himself: he claims not to have enough words, yet immediately finds the right concept - the vacuum cleaner-as a metaphor for this lack. Through this mirror game, the anthropomorphisms function self-reflexively to play with the ways in which the book itself-made up of language-'surrounds experience'. As if winking at the reader, Wainaina challenges the impossibility of telling oneself, or of capturing his point of view, leaving it open-ended rather than undoable.

\section{Temporality and self-writing as elements of teacherliness}

The anthropomorphism, together with the use of short sentences and sounds effects ("whoosh"), all seem to convey a child's view of the world. Yet, at the same time, the sophistication and humor, and the foreshadowing of the future in the line "one day, one day I will arrange the words", also play on the tension between Binyavanga-the-adult looking back and Binyavanga-the-child anticipating, both reinterpreting, indeed, finding words.

As Apollo Amoko writes using Lejeune's concept of the 'autobiographical pact', the text "enact[s] a reversal of the linear progression of time" (203). But while Amoko remarks that autobiographical texts derive authority from being "not simply literally true but also personally experienced" (203), temporality in One Day functions to undercut such a clear segue between life (past) and representation - the latter standing in not only for the present, but for the recursive temporality of hindsight.

Wainaina himself describes this anachronism: "Hindsight will pull facts to its present demand; it is the dental brace that will reshape your jaw, your resolve. When hindsight desires enough, it obliterates uncertainty. All the selected past becomes an argument for action" (One Day I Will Write About This Place 59). As before, anthropomorphism here functions through inconsistencies. For contrarily to what Binyavanga claims, looking back does not obliterate uncertainty.

Retrospection is both constructed and constantly evolving, even if pinned down momentarily by the act of writing. As Hoad explains, "[ $t$ ]he past for Wainaina is always being reimagined from the exigencies of the present" (186). Though this holds true for all autobiographies, the self-reflexivity in Wainaina's engagement with time clearly echoes his preoccupation with language, suggesting that this is part of the book's teacherly ethos-its constant, repetitive need to question itself; to provoke thought and doubt through humorous and innovative imagery.

Temporality thus becomes instrumental in the book's negotiation of self-writing as both medium and theme. One keyword in particular - thirst-bridges past and future in regard to the process of writing as self-reflexive representation. First, at the very beginning, seven-year-old Binyavanga becomes aware of language: "This word, thirst, thirsty. It is a word full of resolution. It drives a person to quick action. Words, I think, must be concrete things. Surely they cannot be suggestions of things, vague pictures: scattered, shifting sensations?" (One Day 5)

Much later, when in his twenties he realizes that he wants to become a writer, the same word lies at the core of his self-doubts. Yet the narrative style has changed: the sentences are no longer short, simple, and repetitive. 
Instead, Wainaina structures his thoughts through doubleness: for each claim, there is a parallel part that is either a repetition, the opposite, or a conditioning of the first:
A
$\mathrm{B}$
A
B
A
I am afraid. If I write, and fail at it, I cannot see what else I can do. Maybe I
B
A
will write and people will roll their eyes, because I will talk about thirst, and
B A $\quad$ B
thirst is something people know already, and what I see is only bad shapes that

mean nothing. (143)

This AB structure gives a rhythmic, almost prosodic register to the intersection between past, present, and future that the word "thirst" evokes, while drawing on an oral aesthetic of repetition, where sentence segments are paired around a juxtaposition of fear/failure against Wainaina's writing. Here I follow Eugene B. McCarthy and Christopher N. Okonkwo's readings of Achebe, where they excavate antiphonal structures in the text. Like the two scholars, I consider Wainaina's text, especially its use of twofold AB structures, as a narrative device that foregrounds rhythm and repetition as a sensibility of orature. Comparing the two conceptions of "thirst", we recognize the growth from child into adult into artist: if at first Binyavanga is unsure of the function of language itself, this turns into an anxiety regarding his own ability to represent himself through language. Furthermore, the doubling sets up fear/failure as parallel to writing/not writing. Like the two images at the end of the paragraph above - "bad shapes" that "mean nothing" - Wainaina uses a question-posing rhetoric, to use Freire's term, through the theme of failure: what if words can't capture experience? Or worse, what if Wainaina can't?

This theme becomes more pronounced throughout the book, and like here, also pertains to the duality of individual and collective. For in the last, long sentence, the twofold structure has an A part that focuses on future Binyavanga: "I will write", "I will talk", and "I will see". The following B part is the imagined response from "people"-the readers-which implicitly points to the future, and to an imagined collective. Referencing the readers also creates a mise-en-abyme effect where the world outside the text is drawn into it, suggesting that we-the real readers-play a part in the story, making it necessarily unfinished. Implicitly entailed is the question of addressee. To whom is this teacherly aesthetic directed? To (East) African readers? To readers of "world literature"? To the global citizen?

Rather than suggest a definitive answer to these questions, it might be more useful to consider the mise-enabyme as a reader-centred moment that explicitly foregrounds the reader's role in making his/her own interpretation of it. As Jesse Weaver Shipley has argued, it seems as if Wainaina's text makes the point that "[s]ustained uncertainty alternately encourages participants to find new meaning in unexpected connections and innuendos and frustrates those who seek definitive interpretations" (10). The question of the implied audience also foregrounds Wainaina's national situatedness, bringing me back to Wainaina's more direct engagement with the educational system in Kenya. Wainaina contextualizes his own experiences at school within national and global processes taking place in Kenya, as Madhu Krishnan notes: "Like the patterns of his life that do not fit together, so pulse the incongruous idioms of the nation" (80). In other words, I focus on the specific stakes of narrative teacherliness in the East African context.

\section{The literature-literacy conundrum}

The explicit engagement with representation and hindsight, and its aesthetic negotiation through doubling and defamiliarization, uses the difficulty and open-endedness of narrative time to oil the mechanisms of self-writing. But this is only one aspect of Wainaina's teacherly ethos, which is supported by his more direct engagement with education.

Formal schooling is a central theme in One Day, one that often intersects with the episodes that predict Binyavanga's artistic and writerly tendencies. His thoughts on education are, above all, contradictory: he describes how public education in Kenya is deteriorating due to the IMF's structural adjustment program, while calling the educational system "Kenya's single biggest achievement", and "truly the only thing that works in Kenya" (90). This is all the more surprising after his own schooling (most of it before the structural adjustment era) is tainted by tribal biases, hierarchies, and corruption $(60,64,84)$. 
Much like Krishnan's reading of the nation/nationalism in One Day, "the contradictory, complementary, and contrarian play of multiple levels of idealization and renunciation that resound across the narrative" (79) mark Wainaina's representations of education in Kenya, as he becomes increasingly conscious of how deeply education is embedded in politics and global networks of power. Here his hindsight hints at his investment in educational thought.

What Krishnan calls idealization and renunciation is, in One Day, reflected in a rhetoric that moves between narratives of failure - such as his fear of failing to write well — and the foreshadowing of his later success as a writer, such as the statement "One day, I will write about this place" (152). While much of the tension between failure and success pertains to his future writing, it is Wainaina's inconsistent educational experiences that ultimately allow him to question the categories of failure and success, as he oscillated between academic requirements and what really interests him-fiction. The two forms of learning, formal and informal, authoritative and learner-centred, underlie Wainaina's negotiation of both school and writing.

The "shifting and often simultaneous deployment of belonging and alienation" (Krishnan 79) is nowhere as evident as in Wainaina's sense of 'belonging' to school. From the book's first page, Binyavanga speaks of the centrality of school in his life, describing himself as one of the best pupils in class $(56,59-60)$. But he also frequently cuts class to read: "I am still reading novels everywhere, and I am always in trouble with Mum" (55). In high school, he not only reads books, but also starts producing literature as an alternative to studying: "I spend all useful time in my advanced-level years making plays and novels, or reading and looking for scholarships in America with my best friend, Peter Karanja, who loves novels as much as I do. I do not study much" (87).

Though Binyavanga never refers to it in explicit terms, reading and creative writing become his informal education, carried out at the expense of his formal schooling. It is his spontaneous critique of his schooling, and his first experience of being learner-centred: educating himself. Paradoxically, his autodidacticism draws him away from school, while also making him one of the top students in English in Kenya in his fourth form exams (87).

The collision between education and writing is perhaps most pronounced when Binyavanga starts university:

After school, I spend a term at Kenyatta University, doing an education degree and majoring in French and literature in English. I am terrified I will end up becoming a schoolteacher. A fate worse than country music. Ngũgĩ wa Thiong’o is a writer and playwright, a Kenyan playwright, and people say he says that women should not perm their hair or wear lipstick. I have permed my hair. I like it. [...]. I love writing. I love the theatre. I fear writers; they want to go too deep and mess up the clear stepladders to success. I cannot see myself being this sort of person. (87-8)

In the same paragraph, Binyavanga claims to be afraid of becoming both teacher and writer, framing both vocations in a terminology of failure, albeit humorously: one a fate worse than country music, the other messing up the clear stepladders to success.

Though the two careers seem mutually exclusive in this context, the example of Ngũgĩ connects the two: Ngũgĩ is the kind of writer Binyavanga cannot imagine himself becoming because the latter follows the old prism of 'the novelist as teacher', telling the young generation what to do and not to do. Moreover, Ngũgĩ, who perhaps more than anyone embodies the teacherliness of East African literature, situates Wainaina's teacherly rhetoric within the specific Kenyan context and its literary history: after all, Ngũgĩ not only represents the African-languages side in the language debate, but also pioneered the abolition of Eurocentric university English departments.

Yet Binyavanga is not so easily convinced by Ngũgîs teacherliness: he likes his perm. Likewise, the idea of becoming a teacher is unappealing because it represents old-school teaching that is hierarchical and authoritative, or worse, corrupt. Binyavanga also does not want anyone to mess up the stepladder to success-the importance of school-for he is a good student after all. As Krishnan remarks about the Kenyan nation, its educational system also "unfurls in a complex and often-contradictory network of affiliations and disavowals, sites of engagement and disillusionment" (79), leading to anticipated and often contradictory dreams of failure and success that are as humorous as they are serious. The contradictions between society's conflicting expectations are even more pronounced when, a few pages later, Binyavanga reads Ngũgĩ and tries to reconcile the latter's teacherly ideal with what Jean Comaroff and John Comaroff call multiple African modernities (118-20): "I read Decolonising the Mind by Ngũgĩ wa Thiong'o a few week ago. It is illegal and it was thrilling, and I had vowed to go back to my own language. English is the language of the colonizer. I will take Gikuyu classes, when I am done with diversity and 
advertising, when I am driving a good car. I will go to the village and make plays in Gikuyu, in my good new car. I will make very good decolonized advertisements for Coca-Cola. I will be cool and decolonized. An international guy. Like, like Youssou N'Dour. Even Ngũgĩ is in America" (One Day 92).

\section{Narratives of failure}

Ultimately, Binyavanga's ferocious reading habits are both the result and the downfall of his success as a student, a process which culminates in the years he spends in South Africa. He goes there to do a degree in finance and marketing at the University of Transkei (93), yet finds himself attending class less and less, until he effectually drops out and spends most of his time reading books alone in his room (104-5). He never completes his degree, so that when he comes home to his parents, years later, there is a mutual understanding of failure: "They are worried about me and, for the first time in my life, worried enough not to bring it up. I have not spoken to them about my stalled degree in a long time. They know. I know" (128).

Speaking in terms of failure and success is a recurring strategy in Wainaina's contradictory engagement with teacherliness. But this changes when he has his epiphany regarding his true vocation. It takes place during a night of dancing, talking, and drinking in upcountry Kenya as part of his work in agricultural extension for his father's company - a job he is given after failing to get a degree in South Africa. Right before his moment of inspiration, he starts formulating his thoughts in a manner than conveys a profound teacherliness:

Our shells crack, and we spill out and mingle. I care so much for these things that sit under the burping self-satisfaction of the certificated world. Maybe I am not just failing; maybe there is something I have that I can barter, if only for the approval of those I respect. [...] Maybe I can help people see the patterns they take for granted. (141)

Like the somewhat drunk and ecstatic state of the scene itself, the figurative language defamiliarizes the clear-cut lines that have had such a decisive role in his life: failure/success, certificate/knowledge, himself/others.

What he earlier called "the clear stepladders to success" he now sees as "the burping self-satisfaction of the certificated world", possibly because he has not been able to turn his good grades into the predicted success. The phrase "maybe I am not just failing" in particular resonates his old and constant fears of not being able to convey meaning, of not meeting his parents' expectations, and of the vagueness and inconsistencies that have marked his engagement with the world around him.

The paragraph is set up as a dialogue between the collective and the individual, starting with the dancing crowd that surrounds him, into which he embeds himself using the words "our" and "we". He returns to his own emotions ("I care so much"), but these are focused on the collective of the "certificated world". He then uses the metaphor of bartering — reciprocity — and social approval as measures of success, referencing "those I respect" as collective that constitutes his self-worth. As Ayelet Ben-Yishai claims, the text functions to construct categories of belonging, "[c]reating, maintaining and reifying these commonalities - generating a 'we"' (204). Put differently, Wainaina uses the narrative not to reflect on the collectives around him, but to construct them.

Finally, the ethical and public sentiments of caring, bartering, and gaining approval lead him to a new definition of success: "help[ing] people see the patterns they take for granted". Binyavanga uses the word patterns frequently to describe both flow and coherence, as well as expectations and rigidity, in people's behavior. "Patterns" is also a term Binyavanga uses frequently to describe himself and others. As such, it captures his oscillation between positive and negative, between consistency and inconsistency: "We assume whole things, when a stranger's movements show a pattern that seems consistent but a single sharp contradiction arrives and a person becomes not whole but a series of mistakes: bits and parts" (One Day 93). Perhaps in this context it also suggests a breach in his own patterns: his fear of becoming a teacher.

The oscillation between individual and collective marks a turning point in Binyavanga's view on meaning-making and education, where he tears himself free from the tyranny of formal school as the only equivalent of learning. The teacherly sentiment in this statement follows the logic that has been set up in Wainaina's self-reflexive engagement with language and temporality: he does not wish to impart knowledge or meaning (though this is arguably the 'something' he has to barter), but to open up knowledge and meaning to new interpretations that 'people' - be it of 'those he respects' or the readers - need to find for themselves - to see what they take for granted.

Arguably he has been teacherly in this sense all along, at least retrospectively. But this is the moment of clarity, followed soon after by a more concrete realization of his desire to become a writer. The moment is told using 
an $\mathrm{AB}$ structure similar to the one above, where sentence segments form dualities that repeat, rephrase, or add to each other:
A
B A
B
A
It is clear-so clear. All this time, without writing one word, I have been
B
A
B
reading novels, and watching people, and writing what I see in my head,

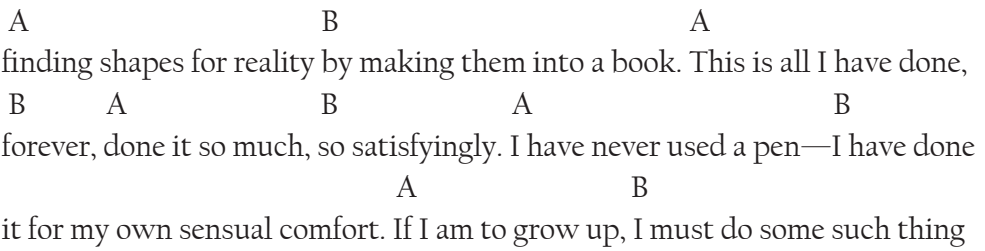

for others. (143)

By equating growing up with doing something for others, Wainaina seems to echo the old ethical premise of the novelist as teacher.

Yet the repetition of each statement privileges a reading that is grounded in doubling rather than straightforwardness. For the paragraph highlights oral aesthetics of repetitions and rhythm-much like Binyavanga's realization that he has, in fact, been 'writing' orally all his life, without using pen and paper. It thus marks a distinction between past ("all this time") and future ("grow up"), between private ("for my own sensual comfort") and public ("for others"), oral ("finding shapes for reality") and writing ("making them into a book"). The way Wainaina uses these binaries to scaffold his idea (l) of "do[ing] some such thing for others" also sets up education and writing as another explicit duality: writing in this paragraph is equated to teaching.

However, because of the many contradictory instances that foreshadow this moment, which have repeatedly demonstrated the shortcomings of both representation and education, writing/teaching is not reduced to a didactic enterprise. Indeed, the early phases of Binyavanga's process of writing are enabled not in spite of, but because of his failures and oral skills-his 'finding shapes for reality', e.g., in metaphors and anthropomorphisms.

Much like Binyavanga's reading habits that constitute both failure and success in the narrative, the process described in this paragraph offers new ways to think about learning — and specifically the many registers of orality that undergird both classroom and informal instruction. As such, Wainaina's self-reflexive description of how he writes reflects on how he envisions teaching: as a dialogue in which self and others engage together in finding shapes for reality, in a process that brings formal and informal modes of learning together-much like Freire's idea of problem-posing education. But what Wainaina adds to the educational paradigm of learner-centred education that foregrounds dialogue, open-endedness, and critical thinking, is his deconstruction of the binary of failure and success.

\section{Implications: Returning from literature to educational theory}

Wainaina's questioning of categories of failure and success is a significant intervention that echoes critiques of learner-centred education in African contexts. As Richard Tabulawa notes, learner-centredness purports to promote "individual autonomy, open-mindedness and tolerance for alternative viewpoints. All these are in line with the individualistic Western culture", so that "learner-centredness invariably promotes the reproduction of capitalism in periphery states" (1l-2). Moreover, CCP is overwhelmingly "promoted by international donor agencies for ideological purposes rather than for realising educational or pedagogical objectives" (Altinyelken 154), making it, paradoxically, a North-to-South, top-down framework: participatory education that is introduced in the most authoritative manner.

What is more, the implementation of learner-centred educational reforms is often met with severe challenges as teachers do not feel there is anything wrong with their pedagogical practices or find themselves overwhelmed by a new system without the necessary training or learning materials. At the same time, teachers also recognize the advantages of such reforms, for instance in making learners more active in their education, and better prepared for life in the informal work market. ${ }^{5}$

This is where Wainaina's engagement with teacherliness might be helpful in tracing the ways in which learner-centredness remains multi-layered and contradictory but might still serve as a foundation for growth. 
Wainaina's theme of 'not just failing' offers a productive way to think through this paradox — and others-without reducing them to one-dimensional fiascos. Indeed, Elizabeth Metto and Lazarus Ndiku Makewa argue that learner-centred teaching would allow Kenyan youths to "be prepared effectively to face life challenges of the $21^{\text {st }}$ century" (23), showing that in the dynamic and heterogenous educational system of Kenya, there is no one-sizefits-all way towards better education.

Perhaps, as Angeline M. Barrett has argued, the key is not to view learner-centred and teacher-centred pedagogies as mutually exclusive, but to recognize the conditions and dynamics in which they complement each other. For instance, even if Wainaina advocates for a kind of teacherliness in which he, as writer and activist, is not seen as an authoritative teacher, but rather as a question-posing member of society, much of his influence is no doubt linked to his status as celebrity and public intellectual: it is at once teacher-centred and learner-centred.

Likewise, though there remains a tension between top-down (and North-to-South) educational models and local grassroots practices, the two are more often than not intertwined. In the context of CBC in Kenya, this movement beyond either/or narratives might suggest that a slow and partial move to learner-centred education is not indicative of the failure (or success) of the reform, but rather should be seen as one of many steps in a complex process towards better education in Kenya. The task is to see which elements work and in which contexts, while recognizing the inseparability of various forms and orientations of education. Both literature and literary theory might be a useful tool towards this end, especially as these display a kind of teacherliness in which "uncertainty and contradiction can be modes of knowing" (Shipley l).

Just to suggest a few possible readings, we might think of existing modes of learning that still function outside or alongside school (mentorship, community, parenthood) as proper education; or see alternative modes of knowledge production such as oral skills, or oral pedagogy, as valuable in and of themselves, and not just as failures of rote learning or cramming. ${ }^{6}$

At the same time, Wainaina's teacherliness might also suggest that we re-think narratives of failure that pertain to East African literature, for instance the claim that local publications are "poorly designed, poorly edited, and poorly marketed" (Wa Ngũgĩ, Rise 157) because East African presses are "still functioning on the rationale of educational publishing" (148). Maybe they, too, are not just failing, but rather functioning according to a teacherly rationale that is obliterated by the new privileging of learner-centred teacherliness, or by the either/or view of literature as educational or as aesthetically driven.

\section{Conclusion}

In this paper, I have discussed how Binyavanga Wainaina's work negotiates ideas of teacherliness in his memoir One Day I Will Write About this Place. I've shown how Wainaina's texts correspond to the Zeitgeist of contemporary African literature, and also of current educational theory, while maintaining their rootedness in East African literary and educational discourses.

Through the lens of Critical Pedagogy, I have outlined how these discourses give an incomplete picture regarding how the two realms of letters have informed each other, both in the past and in the present. Though the full extent of the influence of the 1962 Makerere conference on the East African literary scene is beyond the scope of this paper, my main point is that pedagogical questions were left out of debates following the conference, and that this is an ongoing omission.

By bringing literary and educational theory back into dialogue and excavating their historical links in East Africa, and their present turn with the introduction of the CBC reform, I offer a framework for understanding Wainaina's often-contradictory engagement with education and suggest that East Africa is pivotal for understanding the literature/literacy duality in African literature more broadly.

To this end, I have used educational theory to think through the way Wainaina engages with educationboth as a theme and as aesthetical-pedagogical devices in the text. Focusing on Wainaina's use of metaphors and temporality to foreground the self-reflexive stakes of the autobiography as a genre, I have zoomed in on a repetitive $A B$ structure that draws on oral sensibilities to construct teacherliness within the tension between private/ public, past/future, oral/written, and failure/success.

Through these readings, my main argument has been that Wainaina sets up teaching/writing as an important duality that undermines a binary view of failure and success. This, I argue, allows literary and educational theory to illuminate each other's blind spots, specifically in regard to the new CBC reform, as 'not just failing'. It also offers an example of how aesthetics and political readings scaffold each other. Finally, I suggest avenues 
for further research on both literature and education, for instance on the use of oral patterns and skills as part of classroom practice.

\section{Acknowledgments}

Research for this article was supported by the Martin Buber Society of Fellows in the Humanities and Social Sciences at the Hebrew University of Jerusalem. I'm also grateful to Professor Louise Bethlehem for her insightful comments on drafts of this article, and to Jeanne-Marie Jackson for introducing me to Harry Garuba's work on Teacherly Texts.

\section{Notes}

1. Transition magazine gave a publishing platform to of a group of thinkers that included Ngũgĩ wa Thiong'o (then James Ngugi), Okot p'Bitek, Rebecca Njau, and Ezekiel Mphahlele. Billy Kahora traces the group to the "Makerere Writers Club", corresponding to what later became known as the "Makerere school" of thinkers, which also included Jonathan Kariara and John Nagenda who had attended the conference, as well as Taban lo Liyong, Peter Nazareth, and David Rubadiri.

2. The explicit connection made at the conference between literature and language instruction is imbued with idealism: according to the 1961 conference report, educators are given the task of teaching "fiction in English with enjoyment and appreciation" (14), of encouraging pupils "to develop the capacity for enjoying one of the most important arts practiced by English-speaking people" (15), to remember that "wide reading should be the keynote" (15), and to "provide as much intrinsic motivation as possible" (16). British culture was the core of this lofty project: "Reading should include fiction or works of the imagination because such writing is an essential part of English, because it offers an unique and satisfying human experience, and because the language cannot properly be learnt without it" (14).

3. The 1964 conference in Leeds led to the establishment of The Association for Commonwealth Literature and Language Studies (ACLALS) and The Journal of Commonwealth Literature. For further details see James Currey's article "Ngũgĩ, Leeds and the Establishment of African Literature" in the Leeds African Studies Bulletin, where Currey traces the role that the University of Leeds played in the African literary community, focusing on the time Ngũgĩ spent at Leeds on a British Council scholarship (1964-7)

4. Dozens of authors shared long and detailed accounts of what Wainaina had meant to them. Among these were Isaac Otidi Amuke, Billy Kahora, Pwaangulongii Dauod, Judy Kibinge, Ike Anya, Niq Mhlongo, Parselelo Kantai, A. Igoni Barrett, Yvonne Adhiambo Owuor, Sada Malumfashi, Oris Aigbokhaevbolo, Norbert Odero, Dami Ajayi, Nanjala Nyabola, and Romeo Oriogun. While having different levels of acquaintance with Wainaina, they describe him in surprisingly similar ways: all speak of his generosity in terms of time and feedback. All mention his genuine interest in their work and how he opened doors for them. A recurring story is of how he answered emails from aspiring writerseven those he barely knew - quickly and thoroughly, later following up on the correspondence. All describe a chaotic, lively, politically engaged force of nature who, above all, loved talking about grand ideas, and who created a community around him.

5. For instance, Jane Amunga, Dinah Were, and Irene Ashioya found that over 90\% of teachers felt the CBC was indeed making learners more enthusiastic and involved in their studies (69), yet they found that most parents were unhappy about the active role they were supposed to take in their children's learning (67-8). Like them, Marion Daina, as well as Eliud Wambua Muasya and Samuel N. Waweru, also show that the CBC's implementation in Kenya faces many challenges that are typical of educational reforms in low-income countries: understaffing, high teacher-pupil ratios, inadequate teacher training, meagre parental involvement, and a lack of learning materials, particularly for digital literacy. Nevertheless, all researchers also found that $\mathrm{CBC}$ has benefits if integrated well.

6. The term oral pedagogy has been used to describe processes of learning and communicating knowledge that are not written-based, which offer an alternative to "writing-based consciousness" (Haynes 96). See works by Lance W. Haynes, Jeffery Dryer, Madonna Stinson, and Robin Alexander for examples. Daniela Merolla considers the many kinds of oral literary productions that have also played a role in African structures of education, and which continue to be influential both side-by-side with formal education, and through evolving new media formations.

\section{Works Cited}

Adichie, Chimamanda. "Binyavanga Wainaina." Time. 23 Apr. 2014. https://time.com/70795/binyavanga-wainaina-time-100/.

Alexander, Robin. "Culture, Dialogue and Learning: Notes on an Emerging Pedagogy." Exploring Talk in School: Inspired by the Work of Douglas Barnes, edited by Neil Mercer \& Steve Hodgkinson. SAGE, 2003, pp. 91-114. DOI: http://dx.doi. org/10.4135/9781446279526.n6.

Altinyelken, Hülya K. "Pedagogical Renewal in Sub-Saharan Africa: The Case of Uganda." Comparative Education vol. 46, no. 2, 2010, pp. 151-71. DOI: https://doi.org/10.1080/03050061003775454.

Amoko, Apollo. "Autobiography and Bildungsroman in African Literature." The Cambridge Companion to the African Novel, edited by F. Abiola Irele. Cambridge U P, 2009, pp. 195-209.

Amunga, Jane, D. W. \& Irene Ashioya. "The Teacher-Parent Nexus in the Competency Based Curriculum Success Equation in Kenya." International Journal of Educational Administration and Policy Studies vol. 12, no. 1, 2020, pp. 60-76. DOI: https://doi. org/10.5897/ijeaps2020.0646.

Amutabi, Maurice N. "Competency Based Curriculum (CBC) and the end of an Era in Kenya's Education Sector and Implications for Development: Some Empirical Reflections." Journal of Popular Education in Africa vol. 3, no. 10, 2019, pp. 45-66.

Appiah, Kwame A. “New Literatures, New Theory.” Matatu vol. 7, 1990, pp. 57-90. 
Barrett, Angeline M. "Beyond the Polarization of Pedagogy: Models of Classroom Practice in Tanzanian Primary Schools." Comparative Education vol. 43, no. 2, 2007, pp. 273-94. DOI: https://doi.org/10.1080/03050060701362623.

Ben-Yishai, Ayelet. "Walking the Boundaries in Victorian Fiction: Realism as Communal Epistemology." Nineteenth-Century Contexts: An Interdisciplinary Journal vol. 37, no. 3, 2015, pp. 197-214. DOI: https://doi.org/10.1080/08905495.2015.1030838.

Berger, Roger A. "Decolonizing African Autobiography." Research in African Literatures vol. 41, no. 2, 2010, pp. 32-54. DOI https://doi.org/10.2979/ral.2010.41.2.32

Boehmer, Elleke. Postcolonial Poetics: 21st-Century Critical Readings. Palgrave MacMillan, 2018

Comaroff, Jean \& John L. Comaroff. "Theory from the South: Or, how Euro-America is evolving toward Africa.” Anthropological forum vol. 22, no. 2, Routledge, 2012. DOI: https://doi.org/10.1080/00664677.2012.694169.

Currey, James. "Ngũgĩ, Leeds and the Establishment of African Literature." Leeds African Studies Bulletin no. 74, 2012/13. https:// lucas.leeds.ac.uk/article/ngugi-leeds-and-the-establishment-of-african-literature-james-currey/.

Dauod, Pwaangulongii. "Binyavanga." Granta. 13 Feb. 2020. https://granta.com/binyavanga/.

Dembélé, Martial \& Pulane Lefoka. "Pedagogical Renewal for Quality Universal Primary Education: Overview of Trends in Sub-Saharan Africa." International Review of Education vol. 53, no. 5-6, 2007, pp. 531-53. DOI: https://doi.org/10.1007/s1l159007-9066-8.

Edoro, Ainehi. "Waiting for an Angel: Refashioning the African Self." MA Thesis. U of Texas, 2008.

Erdinast-Vulcan, Daphna. "The I that Tells Itself: A Bakhtinian Perspective on Narrative Identity." Narrative vol. 16, no. 1, 2008, pp. 1-15. DOI: https://doi.org/10.1353/nar.2008.0005.

Freire, Paulo. Pedagogy of the Oppressed: $30^{\text {th } A}$ nniversary Edition. Trans. Myra Bergman Ramos. Continuum, 2000.

Garuba, Harry. "Teacherly Texts: Imagining Futures in Nuruddin Farah’s Past Imperfect Trilogy." Boundary 2 vol. 44, no. 2, 2017, pp. 15-30. DOI: https://doi.org/10.1215/01903659-3826609.

Gowda, H. H. Anniah. "The Association for Commonwealth Language and Literature Studies Conferences in Kampala." Research in African Literatures vol. 5, no. 2, 1974, pp. 219-22. https://www.jstor.org/stable/3818678.

Haynes, Lance W. "Public Speaking Pedagogy in the Media Age." Communication Education vol. 39, no. 2, 1990, pp. 89-102. DOI: https://doi.org/10.1080/03634529009378792.

Hoad, Neville. "Afterword: Out of Place, Out of Time." Research in African Literatures vol. 47, no. 2, 2016, pp. 186-91. DOI: https://doi.org/10.2979/reseafrilite.47.2.11.

Jackson, Jeanne-Marie. "Comparison Re-Justified.” Cambridge Journal of Postcolonial Literary Inquiry vol. 5, no. 3, pp. 255-61. DOI: https://doi.org/10.1017/pli.2018.18.

Kahora, Billy. "Penpoints, Gunpoints, and Dreams: A History of Creative Writing Instruction in East Africa." Chimurenga Chronic. 18 Apr. 2017. http://chimurengachronic.co.za/penpoints-gunpoints-and-dreams/.

Kalliney, Peter. "Modernism, African Literature, and the Cold War." Modern Language Quarterly vol. 76, no. 3, 2015, pp. 333-68. DOI: https://doi.org/10.1215/00267929-2920051.

Kantai, Parselelo. "Sunset on the Age of Love." The Africa Report. 8 Jun. 2019. https:/www.theafricareport.com/13831/sunseton-the-age-of-lovel.

Kenya Institute of Curriculum Development. "Curriculum Reforms in Kenya: Why Do We Need to Reform Our Education System?". https://kicd.ac.ke/cbc-materials/popular-slides-on-cbc/.

Knighton, Rachel. "Refracting the Political in Binyavanga Wainaina's One Day I Will Write about This Place." Politics e Social Justice: African Literature Today 32, edited by Ernest Emenyonu. James Currey, 2014, pp. 33-46.

Krishnan, Mahdu. "Affiliation, Disavowal, and National Commitment in Third Generation African Literature." Ariel: A Review of International English Literature vol. 44, no. 1, 2013, pp. 73-97. DOI: https://doi.org/10.1353/ari.2013.0006.

Lejeune, Philippe. On Autobiography. U of Minnesota P, 1989.

Levine, George. The Realistic Imagination. U of Chicago P, 1983.

MacKenzie, Norman H. "The Place of English in African Education." International Review of Education vol. 5, no. 2, 1959, pp. 216-23. DOI: https://doi.org/10.1007/bf01416596.

McCarthy, Eugene. "Rhythm and Narrative Method in Achebe's Things Fall Apart." NOVEL: A Forum on Fiction vol. 18, no. 3, 1985, pp. 243-56. DOI: https://doi.org/10.2307/1345790.

Merolla, Daniela. "Introduction: Orality and Technauriture of African Literatures." Tydskrif vir Letterkunde vol. 5l, no. 1, 2014 DOI: http://dx.doi.org/10.4314/tvl.v5lil.8.

Metto, Elizabeth \& Lazarus Ndiku Makewa. "Learner-Centred Teaching: Can it Work in Kenyan Public Primary Schools?" American Journal of Educational Research vol. 2, no. 11A, 2014, pp. 23-9. DOI: http://dx.doi.org/10.12691/education2-11A-4

Mphahlele, Ezekiel. "Polemics: The Dead End of African Literature." Transition no. 11, 1963, pp. 7-9.

Mungai, Christine. "In Memory of a Literary Gangster." Al Jazeera. 23 May 2019. https://www.aljazeera.com/ opinions/2019/5/23/in-memory-of-a-literary-gangster.

Narasimhaiah, C. D. "ACLALS Conference on Commonwealth Literature: Kingston, Jamaica, 3-9 January 1971." The Journal of Commonwealth Literature vol. 6, no. 2, 1971, pp. 120-6. DOI: https://doi.org/10.1177/002198947100600216.

Ngũgĩ wa Thiong’o. Decolonising the Mind: The Politics of Language in African Literature. Heinemann Educational, 1986.

Ngũgĩ wa Thiong’o (as James Ngugi), Henry Owuor-Anyumba \& Taban lo Liyong. "On the Abolition of the English Department." The Post-Colonial Studies Reader, edited by Bill Ashcroft, Gareth Griffiths \& Helen Tiffin. Routledge, 2003, pp. $438-42$.

Niven, Alastair. "Obituary: AN Jeffares (1920-2005)." Journal of Commonwealth Literature vol. 41, no. 1, 2006, pp. 141-4. DOI: https://oi.org/10.1177/0021989406062925.

Ojaide, Tanure. "Examining Canonisation in Modern African Literature." Asiatic vol. 3, no. 1, 2009, pp. 1-20. https://journals. iium.edu.my/asiatic/index.php/AJELL/article/view/66.

Okonkwo, Christopher N. "Chinua Achebe's Blue Notes: Toward a Critical Recording of Things Fall Apart's Blues and Jazz Sensibility." Research in African Literatures vol. 47, no. 1, 2016, pp. 109-27. DOI: https://doi.org/10.2979/reseafrilite.47.1.109. 
P’Bitek, Okot. Horn of My Love. Heinemann Kenya, 1992.

Phillipson, Robert. Linguistic Imperialism. Oxford U P, 1991.

Report of the Commonwealth Conference on the Teaching of English as a Second Language, Held at Makerere Conference, Uganda, from 1 to 13 Jan. 1961. Government Printer Uganda, 1961.

Shipley, Jesse W. "Parody after Identity: Digital Music and the Politics of Uncertainty in West Africa." American Ethnologist vol. 44, no. 2, 2017, pp. 1-14. DOI: https://doi.org/10.1111/amet.12476.

Stinson, Madonna. "Speaking Up about Oracy: The Contribution of Drama Pedagogy to Enhanced Oral Communication." English Teaching: Practice e Critique vol. 14, no. 3, 2015, pp. 303-13. DOI: https://doi.org/10.1108/ETPC-07-2015-0055.

Tabulawa, Richard. "International Aid Agencies, Learner-Centred Pedagogy and Political Democratisation: A Critique." Comparative Education vol. 39, no. 1, 2003, pp. 7-26. https://doi.org/10.1080/03050060302559.

Wa Ngũgĩ, Mukoma. The Rise of the African Novel: Politics of Language, Identity, and Ownership. U of Michigan P, 2018. "Our Man of the People." Africa is a Country. 24 May 2019. https://africasacountry.com/2019/05/binyavanga-wainaianaour-man-of-the-people.

Wainaina, Binyavanga. "I am a Homosexual, Mum." Africa is a Country. 19 Jan. 2014. https://africasacountry.com/2014/01/i-ama-homosexual-mum/. One Day I Will Write About This Place. Granta, 2011

"Schooling for Small Minds: Curse of Being an African?" Esin Islam. 1 Sep. 2008. https://www.esinislam.com/ Articles2008/Binyavanga Wainaina/Binyavanga Wainaina 091.htm.

."We Must Free our Imaginations (1/6)." YouTube. 22 Jan. 2014. https://www.youtube.com/watch?v=8uMwppw5AgU. "We Must Free our Imaginations (6/6)." YouTube. 22 Jan. 2014. https://www.youtube.com/watch?v=8FkDm6H6fSO.

Wali, Obiajunwa. "The Dead End of African Literature?" Transition, no. 10, 1963, pp. 13-5. DOI: https://doi. org/10.2307/2934441.

Wambua, Muasya Eliud \& Samuel N. Waweru. "Constraints Facing Successful Implementation of the Competency-Based Curriculum in Kenya." American Journal of Educational Research vol. 7, no. 12, 2019, pp. 943-7. http://pubs.sciepub.com/ education $/ 7 / 12 / 8 /$. 